\title{
Minute Times Micromole Per Liter Per Milligram Per Gram Per Day
}

National Cancer Institute

\section{Source}

National Cancer Institute. Minute Times Micromole Per Liter Per Milligram Per Gram Per

Day. NCI Thesaurus. Code C117959.

Minute times micromole per liter, divided by milligram per gram per day. 